\title{
The field of tension between toxicology and basic and clinical sciences
}

\author{
H. M. Bolt $\cdot$ J. D. Stewart
}

Published online: 9 October 2011

(C) Springer-Verlag 2011

The editors of the Archives of Toxicology find themselves in the difficult situation of deciding whether articles on basic and clinical sciences should remain within the focus of this journal (Bolt and Stewart 2009). In recent years, articles highlighting on basic molecular mechanisms have been particularly encouraged. Nevertheless, it is clear that articles focussing on chemicals and their interactions with healthy organisms and cells remain the major focus of our journal. In order to address the field of tension between toxicology and basic and clinical sciences, we closely cooperate with our partner journal Experimental and Clinical Sciences (EXCLI Journal). Table 1 gives our readers a rapid overview of the key messages of recently published articles in EXCLI Journal.

\section{References}

Abdel-Salam OME, Baiuomy AR, Nada SA (2010) Effect of spironolactone on pain responses in mice. EXCLI Journal 9:46-57

Agbede OO, Ajiboye TO, Kolawole OM, Babatunde SA, Odeigha LO (2010) Evaluation of CD4+ T cells in HIV patients presenting with malaria at the University of Ilorin Teaching Hospital Nigeria. EXCLI Journal 9:58-66

Al-Daoud E (2010) Fast protein classification by using the most significant pairs. EXCLI Journal 9:133-140

Bolt HM, Stewart JD (2009) Toxicology at the interface of basic, applied, and clinical sciences. Arch Toxicol 83:961-963

Dosumu OO, Idowu PA, Onocha PA, Ekundayo O (2010) Isolation of 3-(4-hydroxyphenyl) methylpropenoate and bioactivity evaluation of Gomphrena celosioides extracts. EXCLI Journal 9:173180

H. M. Bolt $(\bowtie) \cdot$ J. D. Stewart

Leibniz Institut für Arbeitsforschung an der TU Dortmund,

Leibniz Research Centre for Working Environment and Human

Factors (IfADo), Ardeystrasse 67, 44139 Dortmund, Germany

e-mail: bolt@ifado.de
Godoy P (2010) Drug metabolism and enzyme induction. EXCLI Journal 9:151-153

Isarankura-Na-Ayudhya $\mathrm{P}$, Isarankura-Na-Ayudhya C, Yainoy S, Thippakorn C, Singhagamol W, Polprachum W, Roytrakul S, Prachayasittikul V (2010) Proteomic alterations of Escherichia coli by paraquat. EXCLI Journal 9:108-118

Kangwanariyakul Y, Nantasenamat C, Tantimongcolwat T, Naenna T (2010) Data mining of magnetocardiograms for prediction of ischemic heart disease. EXCLI Journal 9:82-95

Marchan R (2010) Carcinogenesis and genotoxicity. EXCLI Journal 9:147-150

Meshkin A, Ghafuri H (2010) Prediction of relative solvent accessibility by support vector regression and best-first method. EXCLI Journal 9:29-38

Mukherjee R, Desai F, Singh S, Gajaria T, Singh PK, Baxi DB, Sharma D, Bhatnagar M, Ramachandran AV (2010) Melatonin protects against alterations in hippocampal cholinergic system, trace metals and oxidative stress induced by gestational and lactational exposure to cadmium. EXCLI Journal 9:119-132

Okpuzor J, Ogbunugafor HA, Okafor U, Sofidiya MO (2010) Identification of protein types in Bambara nut seeds: Perspectives for dietary protein supply in developing countries. EXCLI Journal 9:17-28

Patrick-Iwuanyanwu KC, Onyeike EN, Wegwu MO (2010) Hepatoprotective effects of methanolic extract and fractions of African mistletoe Tapinanthus bangwensis (Engl. \& K. Krause) from Nigeria. EXCLI Journal 9:187-194

Porntadavity S, Permpongpaiboon T, Sukketsiri W (2010) Human paraoxonase 2. EXCLI Journal 9:159-172

Prachayasittikul S, Saraban P, Cherdtrakulkiat R, Ruchirawat S, Prachayasittikul V (2010a) New bioactive triterpenoids and antimalarial activity of Diospyros rubra Lec. EXCLI Journal 9:1-10

Prachayasittikul S, Pingaew R, Worachartcheewan A, Ruchirawat S, Prachayasittikul V (2010b) A new sulfoxide analog of 1, 2, 3, 6tetrahydrophenylpyridine and antimicrobial activity. EXCLI Journal 9:102-107

Reif R (2010) Oxidative stress. EXCLI Journal 9:154-155

Saadat M (2010a) N-methyl-D-aspartate receptor NR1 subunit gene (GRIN1) G1001C polymorphism and susceptibility to schizophrenia : a meta-analysis. EXCLI Journal 9:11-16

Saadat M (2010b) Offspring sex ratio at birth and maternal breast cancer risk: a case-control study and meta-analysis of literature. EXCLI Journal 9:76-81 
Table 1 Highlights in experimental and clinical sciences

Key message Reference

Six novel bioactive triterpenoids have been identified that show antimalarial activity

The $\mathrm{C}$ allele of $\mathrm{N}$-methyl-D-aspartate receptor NR1 subunit gene (GRIN1) is associated with increased susceptibility of schizophrenia

Protein types in bambara nut seeds were characterized to evaluate their utility for dietary protein supply in developing countries

A support vector regression-based technique is presented that predicts the solvent accessibility of proteins

Homidium chloride and diminazene aceturate improve anemia in rats

Spironolactone decreased inflammatory visceral pain in a mouse model

The CD4 count was analyzed as a prognostic measure of HIV patients

Transplantation of G-CSF-mobilized peripheral blood monocytes improves the function of cirrhotic livers in rats

The offspring sex ratio is associated with maternal breast cancer risk

A Bayesian neural network-based technique for prediction of ischemic heart disease from magnetocardiograms was established

The impact of traditional chalkboard and PowerPoint teaching on students' performance was better than lecture techniques based on transparencies and overhead projectors

A novel sulfoxide analog of 1,2,3,6-tetrahydrophenylpyridine was established that shows antimicrobial activity

This study compiles proteomic alterations in E. coli caused by paraquat

Melatonin protects against the oxidative effect of cadmium in the hippocampal cholinergic system of mice

A new approach to speed up the protein classification process is introduced

Novel derivatives of 3-(4-hydroxyphenyl) methylpropenoate with anti-microbial activity were identified

Chemical constituents of leaf essential oil with anti-inflammatory activity have been identified

Extracts of African mistletoe leaves have been identified that show hepatoprotective effects

Vascular adaptations to simulated microgravity in rats are associated with altered VCAM-1 expression

A minireview addressing anti-oxidative and anti-atherosclerotic mechanisms of human paraoxonase 2

An overview of metal toxicity, recent developments in genotoxicity research, drug metabolism, oxidative stress, and in vitro systems for toxicity testing are given in a series of editorials

Prachayasittikul et al. (2010a, b)

Saadat (2010a, b)

Okpuzor et al. (2010)

Meshkin and Ghafuri (2010)

Sulaiman and Adeyemi (2010)

Abdel-Salam et al. (2010)

Agbede et al. (2010)

Yan et al. (2010)

Saadat (2010a, b)

Kangwanariyakul et al. (2010)

Seth et al. (2010)

Prachayasittikul et al. (2010a, b)

Isarankura-Na-Ayudhya et al. (2010)

Mukherjee et al. (2010)

Al-Daoud (2010)

Dosumu et al. (2010)

Usman et al. (2010)

Patrick-Iwuanyanwu et al. (2010)

Zhang et al. (2010)

Porntadavity et al. (2010)

Stewart (2010a, b), Marchan (2010), Godoy (2010), Reif et al. (2010)
Seth V, Upadhyaya P, Ahmad M, Kumar V (2010) Impact of various lecture delivery methods in pharmacology. EXCLI Journal 9:96101

Stewart JD (2010a) Metal toxicity. EXCLI Journal 9:144-146

Stewart JD (2010b) In vitro test systems in toxicology. EXCLI Journal 9:156-158

Sulaiman FA, Adeyemi OS (2010) Changes in haematological indices and protein concentrations in Trypanosoma brucei infected rats treated with homidium chloride and diminazene aceturate. EXCLI Journal 9:39-45
Usman LA, Hamid AA, Muhammad NO, Olawore NO, Edewor TI, Saliu BK (2010) Chemical constituents and anti-inflammatory activity of leaf essential oil of Nigerian grown Chenopodium album L. EXCLI Journal 9:181-186

Yan L, Xu S, Wang SZ, Wu B (2010) G-CSF mobilized PBMCs contribute to the liver function of cirrhotic rats. EXCLI Journal 9:67-75

Zhang R, Ran H-H, Gao Y-L, Ma J, Huang Y, Bai Y-G, Lin L-J (2010) Differential vascular cell adhesion molecule-1 expression and superoxide production in simulated microgravity rat vasculature. EXCLI Journal 9:195-204 